\title{
Power Sharing and the Implications for Democratic Governance in Nigeria: The Case of National Assembly (1999-2011)
}

\author{
Yahaya T. Baba (PhD) \\ Department of Political Science \\ Faculty of Social Sciences \\ Usmanu Danfodiyo University, Sokoto
}

Doi: $10.1515 / \mathrm{mjss}-2017-0010$

\begin{abstract}
Given the diverse nature of the Nigerian society and the tension associated with political contestations, particularly elective positions at various levels of government, some power sharing frameworks evolved in both formal and informal contexts. The 'Federal Character Principle' for instance, which is a constitutional provision that requires the sharing of major political and bureaucratic positions among the diverse people of Nigeria is meant to ensure fair representation, equitable distribution of political incentives and sense of belonging. This principle is also internalized by the major political parties in Nigeria in their candidates' selection procedures and indeed by the legislature in determination of candidates for legislative leadership positions. Thus using the National Assembly of Nigeria from 19992011, the paper examined the extent to which formal and informal power sharing arrangements affects democratic governance in the country. The paper relied on secondary sources of data, which include official documents such as the Constitution of the Federal Republic of Nigeria, constitutions of various political parties, newspaper and bulletins and some extant literature. Theoretically, Lijphart's (1968; 1977; and 1990) consociational model of Proportional Representation (PR) provided the guide to understanding the power sharing arrangement in Nigeria's democracy and particularly the informal arrangement within the National Assembly. This theoretical stance, though contradicts the broader theory of legislative institutionalization, is seen as an effective strategy for dousing tensions, curtailing upheavals and ensuring mutual trust among the diverse groups of Nigeria for democratic stability. The paper, however, argues that the informal power sharing arrangement in the Nigeria's National Assembly undermines its autonomy, complexity and the principle of universal procedure of conducting legislative business. Essentially, the power sharing arrangement affects the stability of legislative leadership which is central to legislative autonomy and its institutionalization as well. The paper concluded that while the National Assembly in Nigeria is unlikely to institutionalize conventionally, the fragile nature of the informal arrangements of power sharing may also be a source of tension and conflict once it is obstructed.
\end{abstract}

\section{Introduction}

The imported form of liberal and representative democracy being practiced in Africa is based on some measurable procedural principles, processes and practices. These procedures are geared towards alternating power between and among individuals and groups within defined constitutional and institutional frameworks. The ultimate objective of democratization in Africa, as the case in western societies and other parts of the world, is to guarantee extensive involvement of the people in the constitution and re-constitution of government at prescribed intervals. This way, the basic democratic ideals of participation, accountability and fundamental human rights flourishes, thereby facilitating the attainment of sustainable human development. However, Africa's diversity, as reflected in its peculiar socio-cultural and political organization, poses serious challenge to the growth, development and sustainability of western-style of representative democracy. The unhealthy competition for power between and among diverse groups and the flagrant abuses that 
characterized governance and the conduct of public affairs in democratizing African societies, often segregates the societies into 'citizens' and 'subjects' (Mamdani, 1996).

Thus holders of political power tilt towards exclusionist policy agenda that threaten and in most cases endanger the security and livelihood of different expressions of identities that are either in the opposition or not part of government. As a consequence, democratization across the political landscape of Africa is characterized by tensions and reversals, often times culminating into violent conflicts, civil wars and disintegration of various societies. The ugly experiences of various countries in Africa with democratic transitions provoked theoretical discourse on how to evolve viable and enduring democratic culture across the continent. The concerns, therefore, have been to evolve distinct but appropriate frameworks that could inform unique constitutional and institutional designs capable of accommodating the different expressions of identities in the processes of democratic governance. A number of alternative frameworks abound in the literature that tends to suggest how Africa's crisis-riddled democracy can be modified. Ake's (2000) framework of communal participation, Taylor's (1994) and Englund's (2004) politics of recognition, Lijphart's (1977, 1990) consociational model of Proportional Representation (PR), Horowitz's (1994) electoral systems of Alternative Vote (AV) and Single Transferable Vote (STV) are among other major theoretical prescriptions geared towards addressing the crisis inherent with democracy in plural societies. In these discourses, power sharing appears to be dominant as remedy to fierce competition and conflicts among diverse groups. This way, potentially disadvantaged groups are accommodated and their rights and privileges guaranteed.

These discourses appear to influence the construction and re-construction of political power across different parts of African societies. In Nigeria, for instance, the tensions and reversals that defined the country's democratic history, at a point, necessitates the adoption of quasi consociational approach to political leadership and governance. Thus, power sharing between and among the diverse groups of the Nigeria's population remain central in the country's constitutional engineering from 1979 to date. In particular, the adoption of the principle of Federal Character and Quota System in the 1979, 1989 and the 1999 Constitutions represent a clear attempt by the Nigerian state to mitigate tensions arising from fear of domination of one or some groups of people over others. For instance, section 14(3) of the 1999 Constitution describes the Nigeria's Federal Character Principle as follows:

The composition of the government of the federation or any of its agencies and the conduct of its affairs shall be carried out in such a manner as to reflect the federal character of Nigeria and the need to promote national unity, and also to command national loyalty, thereby ensuring that there shall be no predominance of persons from a few states or from a few ethnic or other sectional groups in that government in any or its agencies.

Accordingly, the composition of government in Nigeria is based on this principle (federal character), which serves as the driving force to promoting inclusiveness and a sense of loyalty of the diverse identities to the state. This suggests fair distribution of political opportunities in ways that ensure the inclusion of diverse groups in governance, thereby guaranteeing the protection of minority rights. The federal character principle is more discernible in the composition of public service, where appointment and recruitment into various positions are done to recognize the rights of various groups to be included in government. In the political realm, the reflection of the federal character and quota system is construed to mean power sharing among the diverse cultural and religious groups in the country. To this end, the executive positions appear to be the major concern of the people. Perhaps, because of the fact that long period of military rule in the country undermined the powers of the legislative branch of government. However, with the return to democratic rule in 1999, a distinct representative legislature emerged and assumed central position in governance and democratic process as provided by the constitution.

The Nigeria's federal legislature is bicameral, consisting of the Senate and House of Representatives, which is known as the National Assembly (NASS). The leadership of the NASS, therefore, occupies an important place in the country's power structure. The Senate, for instance, is headed by a Senate President and the House of Representatives by a Speaker. The former described as the third most important political figure and the latter as the fourth forth, respectively. 
There is also the Deputy Senate President and Deputy Speaker of the House of Representatives. These leadership positions, just like the President and Vice President are apportioned informally to different groups of the society with the view to sharing power and ensuring fair representation of the diverse people of the Nigerian state in the distribution of leadership positions in the political system.

Much as the sharing of executive leadership positions is emphasized, how important is power sharing of the legislative leadership positions in Nigeria's National Assembly? Is power sharing in NASS a remedy to the preponderance of the so-called marginalization of potentially disadvantaged groups? In what significant ways does power sharing arrangement in the legislature affects the leadership quality vis-à-vis the performance of NASS? What are the implications of disregarding the power-sharing arrangement in NASS for Nigeria's democracy? These and other related questions constitute the analytical focus of this paper. Accordingly, the paper is organized into four related sections. The first section, by way of introduction, provided the general background to the challenges of democratization in Africa and the concept of power sharing as a remedy to the crisis inherent with democracy in plural societies. Specifically, the evolution of power sharing arrangement in Nigeria and in particular, its application in the National Assembly set the pace for the discussion. The second section provided the methodology of the study while the third section focused on theoretical contexts of power sharing in divided societies. The fourth section discussed the trends and implications of power sharing in Nigeria's National Assembly for the country's democracy. The last section provides concluding remarks.

\section{Research Design: Qualitative Approach}

Given the nature of the phenomenon at hand (power sharing and implications for democratic governance in Nigeria), qualitative method remain the most suitable approach to providing answers to the research questions raised and achieving the objectives stated. For instance, to examine the contexts within which power is acquired, distributed and consolidated in an emerging democracy, one requires essentially documentary sources. This category of data can only be obtained through the use of qualitative instruments. In other words, this study will rely essentially on qualitative techniques of data collection and analysis.

\section{Documentary Sources}

A large amount of data in the form of public and private archival records is readily available to social scientists. In this case, the researcher made use of relevant documentary sources from the National Dailies, the National Assembly and the major political parties that participated in National Assembly elections from 1999 t0 2011. This way, data is obtained with regard to party nomination of candidates for legislative elections and for leadership positions in the National Assembly. Newspapers, newsletters, and bulletins will also serve as additional sources of documentary information. Archival records also provided tremendous insights for this research.

\section{Data Analysis}

Since three different sources of qualitative data are used, this requires the use of different techniques in the analysis of data from these diverse sources. For instance, analysis of documentary data requires a distinct technique. In this regards, content analysis was used for analyzing data from documentary sources. Content analysis is both a method of data analysis as well as a method of observation. It is is any technique of making inferences by systematically and objectively specifying characteristics of messages. Here, the researcher is basically concerned with the analysis of communications that are documented, instead of making observations or asking questions. Thus, systematic content analysis requires the inclusion or exclusion of content in accordance with consistently applied criteria of selection. This requirement eliminates analyses in which only materials supporting the investigator's hypotheses and/or questions are eliminated. Hence, data gathered from documentary sources are analysed with the use of content analysis. Documentary sources from the political parties, National Dailies, archival records and other private documents were scrutinised to 
elicit relevant information that support analysis of the issues investigated. Reference was made to the stance of some literature reviewed on the research issues at stake. The purpose of this is to establish the connection and/or disparity between the research findings and the relevant literature.

\section{Theoretical Contexts of Power Sharing and Democratization}

The task of deepening democracy in plural and/or divided societies has been a longstanding research agenda among political theorists and scholars in allied disciplines. The argument that plural societies are prone to being divided by deep cleavages of race, religion, language, or ethnicity constitutes a huge challenge for democratic sustainability. Perhaps, because the establishment and sustenance of democratic government is hinged on periodic elections at regular intervals, through which individuals and groups compete for access to political power. Thus the tendency of plural societies to be divided along cleavages, during elections, remains high, constituting enormous risk for regime survival and societal integration. The major source of conflict in these societies has been the question of isolation and/or inclusion. In other words, who among the groups (cleavages) are dominant or subordinate in the power structure of the society? This is usually determined by the population strength of the diverse groups, which most often defined the voting behaviour of the electorate. This is because votes seeking and political mobilization, particularly during elections rests essentially on the use and/or manipulation of identities as against substantive issues of national interests. This gives birth to unhealthy competition and fierce conflicts in a bid to ensure the inclusion of one or some groups and the isolation of others, which breeds tensions, distrust and violent reactions inimical to democratic stability and state survival. In view of this, there have been efforts to theoretically advance appropriate frameworks, particularly electoral systems that can foster the survival of democracy in countries deeply divided by diverse cleavages.

The search for alternative electoral frameworks for plural societies as panacea for the turbulent electoral contestations attracts the attention of not a few scholars. The concerns have been to save collapsing democracies. For instance, Reilly (2001:1156) argues that "is well-known, politicians in such "divided societies" often have strong incentives to "play the ethnic card" at election time, using communal appeals to mobilize voters. "Outbidding" increasingly extreme rhetoric and demands

can offer rewards greater than those of moderation. In such circumstances, politics can quickly turn centrifugal, as the centre is pulled apart by extremist forces and "winner-take all" rules the day. The failure of democracy is often the result". Therefore, democratic theorists shift emphasis on evolving effective strategies, and particularly appropriate electoral systems that could promote interethnic accommodation, multiethnic political parties and centrist politics.

Accordingly, there have been efforts to suggest remedies to sharp social cleavages and segmentations that threaten the survival of democracy. Arend Lijphart's (1968) The Politics of Accommodation and Democracy in Plural Societies (1977) laid the foundation for theoretical discourse of what was to be called consociational democracy. This model of democracy was developed from extensive studies of the features of power-sharing democracy in some selected countries of Netherlands, Belgium and Switzerland. In his analysis of the Netherlands experience, Lijphart (1968) acknowledged the fact that the country was sharply divided along social cleavages of class and religion, yet the country's democracy was stable and effective. Distinguishing democracy from a stable democracy, Lijphart (1968) argues that democracy is a system of government in which people have the opportunity to select their leaders, while stable democracy as one in which the capabilities of the system are sufficient to meet the demands placed upon it. He contends that, Netherlands despite the existence of social cleavages and the polarization and segmentation of the society as reflected in the composition of political parties and groups' representation in parliament, the country's democracy was still relatively stable. This is in contrast to what obtained in Austria, Belgium or France. Two factors are responsible for this paradox: nationalism; and the existence of cross-cutting religious and class cleavages. The first factor promotes unity and the second factor diminishes sharp divisions.

However, there are concerns as to how this framework can be applied to ethnically divided societies in the developing world. This is on the account that most divided societies in developing countries down play nationalism as a driving force for political and electoral contestations and those 
cleavages are hardly cross-cutting, which sharpen social divisions, thereby making conflict not only inevitable but most often violent. As panacea to violent conflict in deeply divided societies, consociationalists advocate for Proportional Representation (PR), which enables ethnic groups to define themselves into ethnically based parties and secure representation in the parliament in proportion of their numbers in the community as a whole (Reilly, 2000). Horowitz (1991) on the other hand, advocated for a design of electoral rules that promote reciprocal vote pooling, bargaining, and accommodation across segmented groups. The Nigeria's presidential elections and Lebanon's electoral system decreed that candidates must secure votes from other regions and ethnic groups. However, Reilly (2000) argues that the most efficient electoral systems that encourage accommodation are those that make politicians reciprocally dependent on votes from groups other than their own. This is the best framework of conflict management in deeply divided societies. The Alternative Vote (AV) and the Single Transferable Vote (STV) are among varieties of electoral systems that encourage accommodation of social and other cleavages as a mechanism for conflict resolution. The former requires that a candidate not only gain plurality but majority of votes cast. If no candidate with absolute majority votes the votes of the lowest candidate are redistributed according to lower preferences continuously until a winner emerges. The latter, on the other hand, is a proportional system multimember district. In this case, quota is determined and candidates with more or equal to the quota is elected and the candidate with the lowest votes is eliminated and his votes re-distributed to candidates left in the race. Surplus votes of elected members are also re-distributed at reduced value until all constituency seats are filled. This system allows even smaller minorities access to representation (Reilly, 2000).

As a consequence, negotiations between and among rival parties, candidates and their supporters for reciprocal votes transfer can enhance cooperation among rival ethnic parties, thereby promoting 'moderate middle' sentiment among the electorate. This approach is regarded as 'centripetalism'- a system that pulls parties towards moderate compromising policies, which reinforce the centre of a deeply divided political spectrum (Sisk, 1995). Reilly (2000) sum up the features of centripetalism into three: (1) the provision of electoral incentives for campaigning politicians to reach out to and attract votes from ethnic groups other than their own....., forcing them to broaden policy positions; (2) the presence of an arena of bargaining, in which political actors from different groups have an incentive to come together and cut deals on reciprocal electoral support; and (3) the development of centrist, aggregative and multiethnic political parties or coalitions of parties that are capable of making cross ethnic appeals to the electorate ( Reilly, 2000:157). The Nigeria's power-sharing deal can be located within these theoretical assumptions. For one, the 1999 constitution as cited earlier provided for the fair distribution of political opportunities between and among the diverse segmments of the Nigerian state. For another, political parties, particularly in the fourth republic evolved framework that decrees the sharing of political offices, including elective positions between and among different expressions of Nigeria's identities. It is within this context that six geo-political zones ${ }^{1}$, though not recognized in the constitution like the states and local governments, evolved and provides the basis for sharing of key political offices among the groups representing each zone. These zones are: North-west; Northeast; North-central; South-west; South-east; and South-south. This informal zonal arrangement offers the platform upon which electoral incentives are sought by politicians as a result of reaching out to other groups. It also provides the bargaining arena for political actors of diverse backgrounds.

\footnotetext{
${ }^{1}$ There are six geo-political zones in Nigeria that reflects both the geography and culture of the people constituting a particular geo-political. These zones are made up of groups of states as follows: North-west -Sokoto, Kebbi, Zamfara, Kaduna, Katsina, Kano and Jigawa; North-east - Borno, Yobe, Adamawa, Taraba, Bauchi and Gombe states; North-central- Plateau, Nasarawa, Benue, Niger, Kwara and Kogi; South-west-Lagos, Oyo, Osun, Ogun, Ondo and Ekiti; South-east- Enugu, Anambra, Imo, Abia and Ebonyi; and South-south- Rivers, Bayelsa, Cross River, Akwa Ibom, Edo and Delta. The North-west geo-politcal zone is made up of seven states and predominantly Muslims and Hausa/Fulani as the major cultural cultural identity. The North-east consists of six states with large number of Muslims and sizable number of Christians. Ethnically, the zone is populated by minority ethnic and tribal groupings across the six states. The North-central zone is also made up of six states with almost even number of Muslims and Christians. There are also different minority cultural and tribal groupings in the zone. The South-west also has six states and is the zone has one dominant cultural and tribal identity. They are mainly Yorubas, though there is somewhat equal number of Muslims and Christians in the zone. The South-east is however made up of five states and is culturally bound together by the Igbo cultural identity. Majority of the people in the zone are also Christians. The South-south has six states and populated by a variety of minority cultural and tribal identities. However, majority of the people are Christians.
} 
More importantly also, the zonal arrangement encourages the development of multiethnic political parties and coalitions, thereby making crossethnic appeals to the electorate. To this end, how does power-sharing arrangement in the Nigeria's National Assembly influence the country's democracy?

\section{Power-sharing in the National Assembly: What Implications for Nigeria's Democracy?}

The question of sharing positions of power between and among diverse groups of people is predicated on the need to douse tensions arising from the isolation of some groups as a result of electoral defeat. This strategy, often described as consociational politics, is remedial to perpetual conflicts that predominates plural societies, whose democracy and electoral systems are based on winner take-all framework. However, this strategy contradicts the conventional pattern of democratic development. For instance, institutionalization is key to the efficiency political organizations and particularly the legislature (Huntington, 1965; Dahl 1966; and Nelson W. Polsby 1968). However, a legislature can not institutionalise with frequent changes in its membership and leadership. Therefore, legislatures in Africa are bedevilled with crisis of institutionalization. The Nigerian legislatures are no exception. Essentially, the pattern of control and manipulation of the Nigerian legislatures by the executive is a consequence of their incapability and organisational weakness, which indicates apparent lack of institutionalization. This undermines the institutional autonomy of the Nigerian legislatures and point to their limited law-making capacity. Moreover, the constitutional contexts within which legislatures operate in Africa hinder their functionality, efficiency and institutionalization (Mezey, 1983).

Essentially, the power structure of the Nigerian legislature (pattern of distribution of positions of power in the legislature) is unsystematic and contradicts one of the essential elements of legislative institutionalization. The multi-cultural and multi-lingual nature of African societies and the suspicion between and among the diverse populations of various states in Africa is partly responsible for the obstructions in the growth and development of democratic institutions. In response to some of these challenges, constitutional reconstruction efforts in some African states were geared towards diversity management in democratization. The case of Nigeria's Federal Character Principle, a constitutional provision conditioning the rotation and/or sharing of political and bureaucratic positions among the various ethnic, cultural and religious groups in the country is a clear example. Other African states in crisis of democratic transition like Kenya and Zimbabwe also adopt similar consociational strategies for mitigating post-electoral conflicts. The concern of this paper, however, is the adoption and practice of rotation and sharing of legislative leadership positions in Nigeria's National Assembly since 1999 and its effect on the leadership stability of the institution.

For instance, autonomy and/or establishment of boundaries remain an essential element of legislative institutionalization. Polsby (1968) notes that another method of investigating the extent to which an institution has established boundaries is to consider its leaders, how they are recruited, what happens to them and most particularly the extent to which institution permit lateral entry to and exit from positions of leadership (Polsby, 1968:152) In Nigeria, the tenure of legislative leaders in the National Assembly has been very brief. From 1999 to 2011 the Senate has had six Senate Presidents, while the House of Representatives produced five Speakers. Thus in addition to other factors influencing the frequency with which the National Assembly changes its leadership, how does the rotation and sharing of legislative leadership positions affect the efficiency vis-à-vis the quality of democracy in the country?.

This investigation becomes necessary because the practice of sharing political positions stems from the principle of Federal Character which advocates for proportional sharing of all bureaucratic, economic, media and political positions at all levels of government (See section 14 (3) and (4) of the 1999 Constitution). Given this constraint, high leadership turnover is imminent since at a particular period these positions have to be shifted to other zones. With this arrangement, it is difficult for legislative leaders to serve for more than eight consecutive years. This constitutes a great challenge to the actualization of substantial tenure for legislative leaders in Nigeria. The emergence of geo-political zones is responsible for the internalization of sharing legislative leadership positions. Accordingly, if the President of the country is produced from a particular zone, the Vice President, Senate President, Speaker Deputy Senate President and Deputy Speaker must 
come from other zones. This is done in order to ensure balance and fair representation of the diverse groups in governance and administration of the country. This constitutional provision (Federal Character) is equally internalized in the constitutions and conventions of political parties that produce elected public officers in the country.

Given this arrangement, therefore, the maximum tenure of a Senate President or a Speaker of the House of Representatives is eight years of consecutive service, after which the office is to be rotated to another zone. This is also a function of if the incumbent leader in the legislature is reelected. Otherwise, another candidate from the zone could emerge as the leader. It could also be that even if the incumbent legislative leader is re-elected, some of the legislators from the zone could oppose his re-election as leader for the second term. This is because the zone is made up of some states and diversities, which accordingly ought to be rotated as convention may demand. In a situation such as this, longer service in the leadership position of legislature in Nigeria is unlikely. Therefore, if institutionalization is conceived in this context, the Nigerian legislature is unlikely to institutionalize in this fashion.

This situation is worrisome, at least from the perspectives of institutionlists, whose viewpoint of organizational efficiency seems to emphasize stability and specialization. Even Polsby's (1968) pioneering work on the institutionalization of the US House of Representatives was influenced, according to him, by the proposition that "for a political system to be viable, for it to succeed in performing tasks of resource allocation, problem solving, conflict settlement, and so on, on behalf of a population of any substantial size, it must be institutionalised. That is to say, organizations must be created and sustained that are specialized to political activity. Otherwise, the political system is likely to be unstable, weak and incapable of servicing the demands of protecting the interests of its constituent groups" (Polsby, 1968: 144).

In Nigeria, leadership instability in the legislature is largely influenced by the apportioning arrangement that conditioned sharing of political offices including legislative leadership positions. The table below shows the various changes recorded in the leadership positions of the National Assembly since 1999:

\begin{tabular}{|c|c|c|c|c|}
\hline$S / M$ & Name of leader(s) & Duration & Ethnic/Political Zones & Reason for leaving office \\
\hline 1. & $\begin{array}{l}\text { Evans Enwerem (Senate } \\
\text { President) }\end{array}$ & $\begin{array}{c}\text { June, 1999- November, } 1999 \\
\text { (6 Months) }\end{array}$ & Igob/ South-east & $\begin{array}{c}\text { Impeached on account of certificate } \\
\text { forgery }\end{array}$ \\
\hline 2. & $\begin{array}{c}\text { Chuba Okadigbo (Senate } \\
\text { President) }\end{array}$ & $\begin{array}{c}\text { November, 1999-September, } \\
2000 \text { (11 Months }\end{array}$ & Igob/ South-east & Impeached on account of corruption \\
\hline 3. & $\begin{array}{l}\text { Anyim Pius Anyim } \\
\text { (Senate President) }\end{array}$ & $\begin{array}{c}\text { September, } 2000-\text { June, } 2003 \\
\text { (2 Years } 8 \text { Months) }\end{array}$ & Igob/ South-east & $\begin{array}{c}\text { Did not re-contest in the } 2003 \\
\text { general elections }\end{array}$ \\
\hline 4. & $\begin{array}{l}\text { Adolphus Wabara } \\
\text { (Senate President) }\end{array}$ & $\begin{array}{c}\text { June, 2003- March, } 2005 \text { (1 } \\
\text { Year } 8 \text { Months) }\end{array}$ & Igob/ South-east & $\begin{array}{l}\text { Resigned on account of financial } \\
\text { scandal and performance }\end{array}$ \\
\hline 5. & $\begin{array}{c}\text { Ken Nnamani } \\
\text { (Senate President) }\end{array}$ & $\begin{array}{c}\text { March, 2005-June, } 2007 \text { (2 } \\
\text { Years } 4 \text { Months) }\end{array}$ & Igob/ South-east & $\begin{array}{c}\text { Did not re-contest in the } 2007 \\
\text { general elections }\end{array}$ \\
\hline 6. & $\begin{array}{c}\text { David Mark } \\
\text { (Senate President) }\end{array}$ & $\begin{array}{c}\text { June, } 2007 \text { to Date (2 Years } \\
8 \text { Months) }\end{array}$ & Idoma/ North-central & Still in office \\
\hline 7. & $\begin{array}{c}\text { Salisu Buhari } \\
\text { (Speaker of the House of } \\
\text { Representatives) }\end{array}$ & $\begin{array}{c}\text { June, 1999- July, } 1999 \text { (2 } \\
\text { Months) }\end{array}$ & $\begin{array}{l}\text { Hausa/ Fulani/ North- } \\
\text { west }\end{array}$ & $\begin{array}{l}\text { Resigned on account of age } \\
\text { falsification and certificates forgery }\end{array}$ \\
\hline 8. & $\begin{array}{l}\text { Ghali Umar Na'abba } \\
\text { (Speaker of the House of } \\
\text { Representatives) }\end{array}$ & $\begin{array}{l}\text { July, } 1999-\text { June, } 2003 \text { (3 } \\
\text { Years } 10 \text { Months) }\end{array}$ & $\begin{array}{l}\text { Hausa/ Fulani/ North- } \\
\text { west }\end{array}$ & $\begin{array}{l}\text { Defeated in the } 2003 \text { general } \\
\text { elections }\end{array}$ \\
\hline 9. & $\begin{array}{l}\text { Aminu Bello Masari } \\
\text { Speaker of the House of } \\
\text { Representatives) }\end{array}$ & $\begin{array}{c}\text { June, 2003- June, 2007(4 } \\
\text { Years) }\end{array}$ & $\begin{array}{l}\text { Hausa/ Fulani/ North- } \\
\text { west }\end{array}$ & $\begin{array}{c}\text { Did not contest in the } 2007 \text { general } \\
\text { elections }\end{array}$ \\
\hline 10. & $\begin{array}{l}\text { Patricia Olubnmi Etteh } \\
\text { Speaker of the House of } \\
\text { Representatives) }\end{array}$ & $\begin{array}{l}\text { June, 2007- August, } 2007 \text { (3 } \\
\text { Months) }\end{array}$ & Yoruba/South-west & $\begin{array}{l}\text { Resigned on account of financial } \\
\text { misappropriation }\end{array}$ \\
\hline 11. & $\begin{array}{l}\text { Demeji Bankole } \\
\text { Speaker of the House of } \\
\text { Representatives) }\end{array}$ & $\begin{array}{l}\text { August, } 2007 \text { to Date ( } 2 \\
\text { Years } 3 \text { Months) }\end{array}$ & Yoruba/South-west & Still in office \\
\hline 12 & $\begin{array}{l}\text { Aminu Waziri Tambuwal } \\
\text { (Speaker of the House of } \\
\text { Representatives) }\end{array}$ & June, 2011 to Date & $\begin{array}{l}\text { Hausa/Fulani/ North- } \\
\text { west }\end{array}$ & Still in Office \\
\hline
\end{tabular}

Source: Author's compilation; The Law Maker, 2007; 2008; 2009; NASS, 2007; and 2008 
The above table provide clear picture of leadership turnover in both the Senate and House of Representatives since 1999. From 1999 to 2011, the Senate had six Presidents, three of which were impeached or pressurized to resign. In the case of Evans Enwerem, he was in office for only six months. Thereafter, he was impeached and replaced with Chuba Okadigbo. Enwerem's successor also experienced similar fate. Okadgbo was thus impeached after spending eleven months in office. The impeachment of Okadigbo paved way for the election of Pius Anyim Pius as Senate President. Unlike his predecessors, he held office until the expiration of his term as elected Senator. He was therefore in office for 2 years 8 months.

For Adolphus Wabara, he stayed in office longer than the first and the second Senate Presidents. He was elected in June, 2003 and impeached in March, 2005. He thus spent 1 year 8 months. Ken Nnamani, who held the position of Senate President between March, 2005 and June, 2007 enjoyed a relatively stable leadership term. The accumulated period of his leadership is: 2 years 8 months. It is important to note that all the five leaders produced by the Senate from 1999 to 2007 are of Igbo origin, from the South-east geo-political zone. This is because the position of the Senate President was apportioned to the zone in the sharing arrangement agreed at party level and respected by the membership of Senate as part of the constitutional requirements, as stipulated by the Federal Character principle. In the case of David Mark was in office as Senate President 2007 to 2011. This is so, because sharing arrangement changed after the 2007 general elections. The office of the President, which was zoned to the North-west, influenced also the re-zoning of other key political positions of which the Senate President went to the North-central. His tenure is relatively stable. He successfully led the Senate between 2007 and 2011 and was also re-elected into the Senate during the 2011 general elections and as Senate President thereafter.

However, this informal zonal arrangement generated serious crisis after the death of the former President Ummaru Musa Yar'adua. The argument was whether or not the Vice President Goodluck Jonathan, who assumed office after protracted political crisis, can contest election as the president in an utter disregard to the existing zoning arrangement agreed at the party level. Some of the concerns raised were that by the zoning arrangement, the North-west is to produce another president to complete two consecutive terms of eight years. This political crisis within the ranks of the ruling Peoples Democratic Party (PDP) rather intensified acrimony among the diverse groups of the six geo-political zones and reignited the North-South dichotomy in Nigeria's political process. Eventually, the incumbency factor decided the debate and President Goodluck Jonathan contested in the 2011 general elections. This largely explained the quantum of violence recorded in the aftermath of the presidential elections, particularly in the Northern Nigeria. The lost of lives and the destruction of property is the highest in the country's political history. This reaction was a hangover of the crisis of succession that ensued after the death of the ailing President Ummaru Musa Yar'adua.

In the House of Representatives, there was also a similar trend. From inception in 1999, the House produced five Speakers. The first Speaker, Salisu Buhari was forced to resign in less than two months of his term in office. This was after investigations have shown that he falsified his age and presented fake academic certificates. However, for Ghali Umar Na'abba and Aminu Bello Masari, they both completed their tenure after surviving several attempts at impeachment. The former spent 3 years 10 months in office, while the latter was in office for complete 4 years. The two Speakers that served between 1999 and 2007 are of Hausa/Fulani origin from the North-west geopolitical zone. This is because the zoning arrangement at that time allocates the seat of the Speaker to the North-west. So even when Ghali Na'abba was not re-elected, Aminu Bello Masari, from the same zone was elected to fill the quota of the North-west.

However, after the 2007 general elections, the zoning arrangement changed. Thus, the position of the Speaker was re-zoned to the South-west with the election of Ummaru Musa Yar'adua as President from the North-west. Accordingly, Patricia Olubunmi Etteh, from the Southwest was elected as the Speaker of the House of Representatives. However, the relative leadership stability achieved in the lower House was fluxed in August, 2007 when the first female Speaker, was forced to resign her election on the ground of financial misappropriation. She only held sway for 3 months. This paved way for the election of Demeji Bankole as the Speaker of the lower House in August, 2007, also from the South-west zone. Demeji Bankole served as Speaker until the 
expiration of his tenure as a member of the House. He was, however, not re-elected into the House in the 2011 general elections.

However, the zoning arrangement was threatened at the inauguration of the House of Representatives in June, 2011. The PDP, for instance zoned the position of the Speaker to Southwest, but the membership of the House defied the zoning arrangement of the party and elected Aminu Waziri Tambuwal as the Speaker. His election not only obstructed the zoning arrangement but created imbalance in the sharing of political offices among the diverse groups of people that constitutes the geo-political zones of the country. Just like the debate and the crisis that erupted after the death of the former president Yar'adua, the election of Aminu Waziri from North-west, a zone that produced the Vice President is seen by the party and particularly, prominent politicians from the South-west zone as a defiance of party rules and even the Federal Character, which is a constitutional provision. It was reported by one of the daily newspaper after the election of the Speaker as follows:

The House had been locked in crisis since June 6, 2011 when its members overwhelmingly defied the PDP's zoning formula, which allocated the Speakership to the South-west, and elected Tambuwal and Ihedioha from the North-west and South-east zones, respectively as Speaker and Deputy Speaker (Daily Trust, July 10, 2011)

Another newspaper also made similar remarks as follows:

The House of Representatives is heading on another collision course with the presidency on zoning of its principal officers, as the leadership prepares to release the list of principal officials and heads of different House Committees this week (The Tribune, July 11, 2011).

In view of this development, the ruling PDP responded and cautioned the House on the need to respect the rules of the game, particularly as it relates to the zoning arrangement. In one of its emergency meetings the PDP was forced to react:

The Board of Trustees (BOT) of the ruling Peoples Democratic Party (PDP) has constituted a seven-man committee to advise the party on what steps to take following the seeming collapse of the party's internal zoning arrangement for key appointed and elective offices in the party and at the government levels..... Obasanjo, protested against the development in the House of Representatives which stripped the Southwest geo-political zone of the position of Speaker, suggested that House Speaker Aminu Tambuwal and other officers should step down in 2013 to revive the zoning formula (Daily Trust, July 28, 2011).

The reaction of the party and particularly the comments by the former President Obasanjo on the need for the House to reverse the election of the Speaker and respect the zoning arrangement of the PDP also attracted counter reactions even within the ranks of the PDP. Some members of the National Working Committee of the party were first to dismiss the comments of the former president:

Top members of the NWC also disagreed with the comments by former President and chairman of the PDP BoT, Olusegun Obasanjo, describing it as merely playing to the gallery as events have over taken the breach of the zoning system that eventually brought the Speaker of the House of Representatives, Aminu Tambuwal and his deputy, Emeka Ihedioha to office. Former Vice President Atiku Abubakar also described the comments as sheer hypocrisy on the part of Obasanjo (Thisday, 28 July, 2011).

The House of the Representatives was also not left of this political tussle. Justifying its action of the election of the Speaker from a zone other than the one reserved for the position by party, the House asked the PDP to respect the choice of the House, as only it can determine its leadership, as provided by the constitution. One of these reactions suggest that:

The House of Representatives yesterday lambasted former President Olusegun Obasanjo for calling on Speaker Aminu Waziri Tambuwal to resign in 2013 in order to correct the zoning 
arrangement of the ruling People's Democratic Party (PDP) . Rep Victor Ogene (APGA, Anambra) who spoke to newsmen on the issue said Tambuwal is not a Speaker of the PDP but of the House of Representatives. Ogene maintained that it was absolutely improper for the former President to have called for the resignation of Tambuwal because he is not a member of the House of Representatives" (Daily Trust, July 28, 2011).

This reactions and counter reactions by political heavy weights in Nigeria's politics are capable of overheating the polity and may even degenerates into chaos and instability. For instance, the debate on the alteration of the zoning arrangement after the death of the former President Yar'adua is adjudged to be substantially part of the cause of the post-election violence, mainly in Northern Nigeria. Similarly, if the tension that builds after the defiance of the zoning principle by House is not controlled, it is capable of also destabilizing the polity. The zoning arrangement, therefore, if not properly managed could lead to instability rather than harmony, trust and intergroup cohesion among the diverse groups of the Nigeria's population.

\section{Conclusion}

The principle of Federal Character and the sharing of political offices among the diverse groups constitute a great challenge to the actualisation of substantial tenure for legislative leaders in Nigeria. Leadership positions are shared and rotated amongst the six geo-political zones in the country. Thus if the President is produced from a particular zone, the Vice President, Senate President, Speaker, Deputy Senate President and Deputy Speaker must come from other zones. This is done in order to ensure balance and fair representation of the diverse groups and regions in governance and administration of the country. This constitutional provision (Federal Character) is equally internalized in the constitutions and conventions of political parties. In this context, the constitutional provision for sharing and rotating of political offices may appear to have addressed a fundamental problem of domination of one group (ethnic, tribal, regional and religious) over another, but it has also created serious obstruction in the development of legislature. This suffices to argue that Nigerian legislature is unlikely to institutionalise in this contextual reality. This is partly responsible for the weakness of the Nigeria's National Assembly in relation to other branches of government. This is because, as argued by institutionalists a legislature with high leadership turnover is weak and unlikely to institutionalize (Polsby, 1968, Hibbing, 1999, Squire, 1992). This is in addition to the fact that the zoning arrangement itself is fragile. Its fragility is also a major source of conflict and instability. The case of the event of the June 6, 2011 in the House of Representatives and the reactions and counter reactions is a pointer to this assertion.

\section{Acknowledgement}

The Federal Character Principle is a provision in the 1999 Constitution of Nigeria 14(3), which require the composition of the government of the federation and any of its agencies to reflect the diversity of the society in order to ensure equity and fairness in the appointment and distribution of public posts among the diverse ethnic, tribal, cultural and religious groups as a strategy for achieving national unity and commanding national loyalty.

\section{References}

Ake, C. (2000) The Feasibility of Democracy in Africa, Dakar: CODESRIA.

Dahl, R. (1956) A Preface to Democratic Theory University of Chicago Press, United States.

Dahl, R. (1966) Political Oppositions in Western Democracies, New Heaven and London: Yale University Press.

Hibbing, J.R. (1993) "The Career Paths of Members of Congress" In Shirley, W. and Edward, L.L (eds). Ambition and Beyond Jr. Berkeley, CA: Institute of Governmental Studies Press.

Hibbing, J.R. (1999) "Legislative Careers: Why and How We Should Study Them" Legislative Studies Quarterly, Vol.24 No.2 pp 149-171.

Horowitz, D. (1991) Democratic South Africa? Constitutional Engineering in a Divided Society Berkley: University of California Press

Huntington, S.P. (1965) "Political Development and Political Decay" World Politics. pp.386-430. 
Lijphart, A. (1968) Politics of Accommodation: University of California Press

Lijphart, A. (1977) Democracy in Plural Societies New Heaven: Yale University Press

Mamdani, Mahmood (1996) Citizen and Subject: Contemporary Africa and the Legacy of Late Colonialism. Princeton: Princeton University Press.

Mezey, M.L. (1983) "The Functions of Legislatures in the Third World", Legislative Studies Quarterly Vol. VIII, No. $4,511-550$.

Nijzink, L. (2005) "Parliament and Electoral System: How are South Africans Being Represented" in J. Piambo and L. Nijzink (eds) Electoral Politics in South Africa: Assessing the First Democratic Decade (New York): Palm grove Macmillan, pp 64-87.

Nijzink, L. Mozaffers, S. and Azevedo, E. (2006) "Can Parliament Enhance the Quality of Democracy on the African Continent: An Analysis of Institutional Capacity and Public Perceptions", Centre for Social Science Research, University of Café Town, No.160.

Polsby, Nelson W. (1968) "Institutionalisation of the U.S. House of Representatives" American Political Science Review Vol.62: p.144-68.

Reilly, B. (2000) Electoral Systems for Divided Societies Journal for Democracy Vol. 13, No. 2

Rosenthal, Alan (1996) "State Legislative Development from Three Perspectives", Legislative Studies Quarterly, Vol.21 No.2 pp 169-198.

Sisk, T.D. (1995) Democratization in South Africa: The Elusive Social Contract Princeton: Princeton University Press.

Squire, Peverill (1992) "The Theory of Legislative Institutionalisation and the Californian Assembly The Journal of Politics, Vol.4, No. 2 (November) pp1026-54.

Squire, Peverill (1993)“Professionalisation and Politics of Opinion of State Legislatures", The Journal of Politics, Vol.55, No. 2 (May) pp479-91.

Squire, Peverill (1998) "Career Opportunities and Membership Stability in Legislatures" Legislative Studies Quarterly

\section{Newspapers and Magazines}

Daily Trust, July 10, 2011

Daily Trust, July 28, 2011

Legislative Bulletin Vol. 1 No. 1513 October, 2008

Legislative Bulletin Vol. 1 No. 1520 October, 2008

Legislative Bulletin Vol. 1 No. 3711 May, 2009

Legislative Bulletin Vol. 1 No. 376 April, 2009

National Assembly Statistical Information (2007) Vol.1: A Quarterly Publication of the Research and Statistics Division, Library, Research and Statistics Department, National Assembly, Abuja.

National Assembly Statistical Information (2008) Vol. 2: A Bi-Annual Publication of the Research and Statistics Division, Library, Research and Statistics Department, in Conjunction with Policy Analysis and Research Project (PARP) National Assembly, Abuja.

The Lawmaker, Vol. 8 No. 174 September 2007

The Lawmaker, Vol. 9 No. 192 September 2008

The Lawmaker, Vol. 10 No. 209 February 2009

The Lawmaker, Vol. 10 No. 211 March 2009

The Lawmaker, Vol. 10 No. 213 April 2009

The Lawmaker, Vol. 11 No. 193 June 2009

This day, 28 July, 2011 